\title{
Multi-scale synthesis of historical fire regimes along the south-central US prairie- forest border
}

\author{
Molly V. Rooney and Michael C. Stambaugh ${ }^{*}$
}

\begin{abstract}
Background: Along the prairie-forest border in the south-central USA exists one of the most extensive areas of uncut forest in the nation (>323 750 hectares), providing unique potential for developing multi-century records of environmental changes through dendrochronological analyses. Twentieth century changes in vegetation, increased prescribed fire management, and recent years of elevated wildfire activity have increased interest in understanding the region's long-term fire regime characteristics. To address this need, we analyzed and compared fire intervals, seasonality, severity, and extent based on fire-scar history datasets from three new and ten existing study sites.

Results: At the study sites, mean fire intervals ranged from 3 to 10 years prior to Euro-American settlement and generally became more frequent after. The majority of fires occurred in the dormant season and resulted in low percentages of trees scarred. Coinciding with Euro-American settlement (EAS), fire frequencies appear to have varied by geography. At the regional scale, fire regimes have trended towards decreased fire severity and slightly decreased fire intervals over the past 300 years. Further, fires appear to have increased in extent from circa 1770 to the mid to late 1800s, after which it began to decline, circa 1920.
\end{abstract}

Conclusions: Although frequent, descriptions of fire regimes since the eighteenth century should be characterized as time-dependent and spatially variable, likely depending on local socio-ecological influences. Similar influences may explain fire frequency increases following EAS, while fire severity trended lower.

Keywords: dendrochronology, drought, humans, oak, prairie, woodland

\section{Resumen}

Antecedentes: A lo largo del borde entre el bosque y la pradera en el sud-oeste de los EEUU, existe una de las áreas más extensas de bosques sin intervenciones (cortas) de la nación (>323 750 hectáreas), lo que provee de un potencial único para desarrollar registros multicenteniales de cambios ambientales a través del análisis dendrocronológico. Los cambios en vegetación ocurridos durante el siglo veinte, el incremento de las quemas prescriptas, y la elevada actividad de incendios en los últimos años ha incrementado el interés para entender las características del régimen de fuego de la región en el largo plazo. Para abordar esta necesidad, analizamos y comparamos intervalos de fuego, estacionalidad, severidad, y duración obtenidos de bases de datos de cicatrices de fuegos de tres lugares de estudio nuevos y de diez existentes.

(Continued on next page)

\footnotetext{
* Correspondence: stambaughm@missouri.edu

School of Natural Resources, Missouri Tree-Ring Laboratory, University of

Missouri, 1111 Rollins Street, 203L Anheuser-Busch Natural Resources

Building, Columbia, Missouri 65211, USA
} 
(Continued from previous page)

Resultados: En los sitios de estudio, los intervalos medios entre incendios tuvieron un rango de entre 3 a 10 años antes de la colonización Euroamericana y en general se hicieron más frecuentes de allí en más. La mayoría de esos incendios ocurrieron en la estación de dormición y resultaron en un bajo porcentaje de árboles con cicatrices de fuego. Coincidiendo con la colonización Euroamericana (EAS), las frecuencias de incendios parecen haber variado geográficamente. A escala regional, los regímenes de fuegos tendieron hacia un decrecimiento en la severidad del fuego y un leve decrecimiento en los intervalos de fuego en los últimos 300 años. Además, los incendios parecen haberse incrementado en extensión desde ca. 1770 hasta mediados-finales de 1800s, después del cual comenzó a declinar ca. 1920.

Conclusiones: Aunque frecuentes, las descripciones de los regímenes de fuego desde el siglo dieciocho deben ser caracterizados como tiempo dependiente y espacialmente variables, variando asimismo en función de las

influencias socio-ecológicas locales. Influencias similares pueden explicar el incremento de la frecuencia después de EAS, mientras que la severidad tiende a disminuir.

\section{Abbreviations}

EAS: Euro-American Settlement

FEI: fire extent index

GPS: Global Positioning System

K-S: Kolmogorov-Smirnov

MFI: Mean fire interval

NWR: National Wildlife Refuge

WMA: Wildlife Management Area

WMI: Weibull median interval

\section{Background}

In the south-central USA, between the eastern deciduous forest and the Great Plains, is a unique prairieforest ecotone comprised of the Cross Timbers, Blackland Prairie, and Oak-Hickory ecoregions (Kuchler 1964). These ecoregions support a patchwork of forests, woodlands, savannas, and prairies (Fig. 1; Rice and Penfound 1959; Hoagland et al. 1999). Prairies are often located on broad flat landscapes, while forested areas are often associated with more varied terrain, drainages, and areas of low soil fertility. Trees are commonly short, slow growing, and of poor form due to site and environmental factors, thus have limited economic value and, consequently, the region holds one of the most extensive areas of uncut forest in the US (>323750 hectares; Therrell and Stahle 1998), providing unique potential for documenting long-term environmental changes through dendrochronological analyses.

Throughout the Holocene, North American oak (Quercus L.) ecosystems were influenced by variations in climate conditions and repeated fire disturbance (Johnson et al. 2009; Jones et al. 2017). During the last two centuries, fire suppression has resulted in vegetation alterations at a continental scale, including extensive areas of open-canopy oak savannas and woodlands transitioning to more closed-canopy conditions (DeSantis et al. 2011; Hanberry et al. 2014; Stambaugh et al. 2014). For at least the last four centuries, fire regimes were strongly controlled by humans (Guyette et al. 2002; Stambaugh et al. 2016). Native Americans and Euro-American settlers used fire for a variety of purposes related to clearing vegetation, improving forage for grazing animals, controlling pests, warfare, and hunting, among others (Moore 1972; Williams 1989; Stewart 2002). Diseases introduced by Europeans caused Native American populations to collapse and likely further altered fire regimes through reduced anthropogenic ignitions (Waldman 1985).

Improving understanding of long-term changes to ecosystems and human influences could be informed by regional fire regime data. Characterizing regional fire regimes has previously used spatially extensive networks of study sites or modeling approaches (Falk et al. 2007; Yocum Kent et al. 2017). In the eastern US, networks of study sites are currently limited to the Ozark Highlands and Appalachian Mountain regions (Guyette et al. 2002; Lafon et al. 2017; Stambaugh et al. 2018). Although limited, networks of fire history study sites have contributed to understanding historical landscape vegetation patterns (Batek et al. 1999), cultural fire regime changes (Stambaugh and Guyette 2008; Taylor et al. 2016), and climatic controls on fire variability (Swetnam and Baisan 1996; Guyette et al. 2012; Yocum Kent et al. 2017). Recently, elevated wildfire activity and occurrence of high-severity fires has raised interest in understanding the probability and drivers of fire activity (Scasta et al. 2016). Thus, additional work documenting fire regime characteristics is of increasing value to fire and natural resource managers alike.

The objective of this study was to increase the understanding of fire regimes at the south-central US prairieforest border by developing and synthesizing fire-scar history data from a growing network of study sites. We constructed fire-scar records in three new locations that had little to no existing data and collated data from 10 additional sites throughout the region. For each site, we analyzed fire-scar data spanning the last three centuries. 


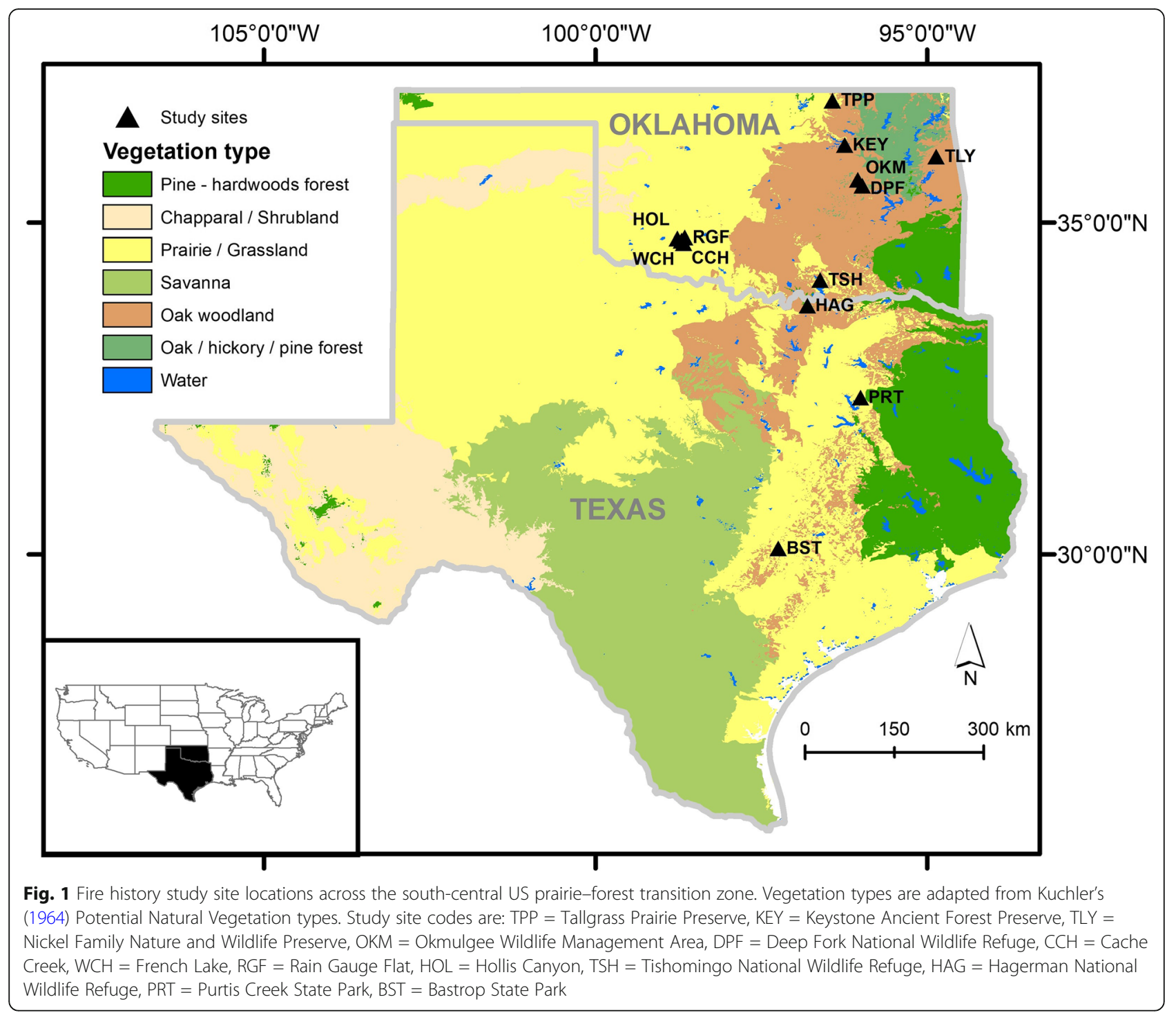

We contrasted site-level fire regime characteristics and then synthesized broad regional characteristics of fire frequency, severity, extent, and seasonality. This synthesis of fire regimes will inform emerging landscape to regional efforts such as conservation of wildlife, range management and eastern redcedar (Juniperus virginiana L.) control, and wildfire risk mitigation.

\section{Methods}

\section{Study sites}

In 2015 and 2016, we surveyed forested US Fish and Wildlife Service National Wildlife Refuges (NWRs) in Oklahoma and northern Texas for potential to establish new fire-scar history study sites. NWRs with post oak (Quercus stellata Wangenh.) were of particular interest because of the species' ability to survive multiple fires, form and compartmentalize fire scars, and live three centuries or more (Guyette and Stambaugh 2004;
Stambaugh et al. 2017a). Potential study sites consisted of areas where up to 50 or more trees with fire scars spanning at least 250 years were located within a $1 \mathrm{~km}^{2}$ area. A sampling area of $1 \mathrm{~km}^{2}$ is commonly used for fire-scar history studies as the area typically captures variable topography, adequate sample material, and allows for the comparison among sites (Falk and Swetnam 2003; Stambaugh et al. 2016).

Three new study sites were established at Hagerman (HAG), Tishomingo (TSH), and Deep Fork (DPF) NWRs (Table 1, Fig. 1). HAG lies at the intersection of the Blackland Prairies and the Eastern Cross Timbers (Omernik 1987). The 5000-hectare refuge was established in 1946 in the southerly portion of the Big Mineral Arm of Lake Texoma (US Fish and Wildlife Service 2006). Topography is gentle to steeply sloping, and soils vary from clays in the south and east transitioning to sandy to the north and west (Spearing 1991). Post 
Table 1 Characteristics of study sites across the south-central US prairie-forest transition zone. Tree species: PO= post oak, SO = Shumard oak (Quercus shumardii Buckley), BO = blackjack oak, BH = black hickory, SP = shortleaf pine (Pinus echinata Mill.). WMA = Wildlife Management Area, NWR = National Wildlife Refuge

\begin{tabular}{|c|c|c|c|c|c|c|c|}
\hline Site name & Site code & Latitude & Longitude & Samples $(n)$ & Tree species & Area $\left(\mathrm{km}^{2}\right)$ & Elevation $(\mathrm{m})$ \\
\hline Bastrop State Park & BST & $30.11017 \mathrm{~N}$ & $97.28690 \mathrm{~W}$ & 50 & $\mathrm{PO}$ & 1 & 145 \\
\hline Cache Creek ${ }^{\mathrm{b}}$ & $\mathrm{CCH}$ & $34.75096 \mathrm{~N}$ & $98.68206 \mathrm{~W}$ & 43 & $\mathrm{PO}$ & 1 & 425 \\
\hline Deep Fork ${ }^{c}$ & DPF & $35.53833 N$ & $95.92761 \mathrm{~W}$ & 48 & $\mathrm{PO}$ & 1 & 240 \\
\hline French Lake ${ }^{b}$ & WCH & $34.75096 \mathrm{~N}$ & $98.68206 \mathrm{~W}$ & 54 & $\mathrm{PO}$ & 1 & 500 \\
\hline Hagerman NWR ${ }^{c}$ & HAG & $33.75546 \mathrm{~N}$ & $96.78152 \mathrm{~W}$ & 51 & $\mathrm{PO}$ & 1 & 205 \\
\hline Hollis Canyon ${ }^{b}$ & $\mathrm{HOL}$ & $34.75096 \mathrm{~N}$ & $98.68206 \mathrm{~W}$ & 46 & $\mathrm{PO}$ & 1 & 535 \\
\hline Keystone $^{d}$ & KEY & $36.18111 \mathrm{~N}$ & 96.22975 W & 51 & $\mathrm{PO}, \mathrm{SO}, \mathrm{BO}, \mathrm{BH}$ & 0.4 & 270 \\
\hline Tully Hollow ${ }^{e}$ & TLY & $36.03435 \mathrm{~N}$ & $94.80823 \mathrm{~W}$ & 34 & SP & 1.2 & 330 \\
\hline Okmulgee $W M A^{f}$ & OKM & $35.64454 \mathrm{~N}$ & $96.04499 \mathrm{~W}$ & 69 & $\mathrm{PO}$ & 1 & 270 \\
\hline Purtis Creek State Park ${ }^{9}$ & PRT & $32.35367 \mathrm{~N}$ & $95.99358 \mathrm{~W}$ & 49 & $\mathrm{PO}$ & 0.5 & 140 \\
\hline Rain Gauge Flat ${ }^{\mathrm{b}}$ & RGF & $34.75096 \mathrm{~N}$ & $98.68206 \mathrm{~W}$ & 46 & $\mathrm{PO}$ & 1 & 535 \\
\hline Tallgrass Prairie Preserve ${ }^{h}$ & TPP & $36.84614 N$ & $96.42290 \mathrm{~W}$ & 54 & $\mathrm{PO}$ & 1.6 & 325 \\
\hline Tishomingo NWR ${ }^{c}$ & TSH & $34.18097 \mathrm{~N}$ & $96.66113 \mathrm{~W}$ & 49 & $\mathrm{PO}$ & 1 & 215 \\
\hline All sites & ALL & & & 644 & & & \\
\hline
\end{tabular}

${ }^{a}$ Data from Stambaugh et al. 2017b. ${ }^{b}$ Data from Stambaugh et al. 2014. ${ }^{c}$ Data from this study. ${ }^{d}$ Data from Clark et al. $2007 .{ }^{e}$ Data from Stambaugh et al. 2013.

${ }^{f}$ Data from DeSantis et al. 2010b. ${ }^{9}$ Data from Stambaugh et al. 2011. ${ }^{\text {h }}$ Data from Allen and Palmer 2011

oak- and blackjack oak (Quercus marilandica Münch.)dominated forests are associated with sandy soils, with black hickory (Carya texana Buckley), eastern red cedar, and winged elm (Ulmus alata Michx.) as important subordinates. TSH is located in south-central Oklahoma (Table 1, Fig. 1) on the south side of the Washita River in the uplands adjacent to Rock Creek, with soil types consisting of sandy loam and cobbly clay (Soil Survey Staff 2009). Post oak and blackjack oak forests are dominant at the site, but small $(<1 \mathrm{ha})$ prairie openings exist, with little bluestem (Schizachyrium scoparium [Michx.] Nash) and big bluestem (Andropogon gerardii Vitman). DPF occurs along a forested corridor of the Deep Fork River on uplands consisting of forested to open lands primarily with sandstone and shale parent materials (Soil Survey Staff 2009). Uplands commonly consist of young post oak and blackjack oak forests $(<120 \mathrm{yr})$, although areas of old growth $(>300 \mathrm{yr})$ can be found. Across these sites, climate is humid-continental, with mean annual temperatures ranging from 15 to $20^{\circ} \mathrm{C}$ and mean annual precipitation ranging from 103 to $110 \mathrm{~cm}$ (for the period 1974 to 2011; Runkle et al. 2017).

Additional fire history data from 10 comparable study sites within the Cross Timbers, Blackland Prairie, and Oak-Hickory ecoregions were contributed by other investigators (Table 1 , Fig. 1). Four of these sites $(\mathrm{CCH}$, HOL, RGF, WCH) are located in the Wichita Mountains on the western edge of the Cross Timbers (Stambaugh et al. 2014). One site (TLY) was located the northeastern edge of the Cross Timbers at the Nickel Family Nature and Wildlife Preserve (Stambaugh et al. 2013). In the northern Cross Timbers, data from the Keystone Ancient Forest Preserve (KEY) and the Tallgrass Prairie Preserve (TPP) were included (Clark et al. 2007; Allen and Palmer 2011). In central Oklahoma, a site at Okmulgee Wildlife Management Area (OKM) was included (DeSantis et al. 2011) and, in central Texas, sites in the Post Oak Savannah ecoregion were included from Purtis Creek (PRT) and Bastrop (BST) state parks (Stambaugh et al. 2011; Stambaugh et al. 2017b).

\section{Developing new fire-scar history records}

Sample trees were selected based on external characteristics of the tree (e.g., missing lower branches, spiral twist of bole, enlarged tree base indicating possible internal wounding) and soundness of the bole. An effort was made to minimize fire scarring bias due to either tree age or size by sampling small to large diameter and young to old trees (Guyette and Stambaugh 2004). Cross-sections were cut from the base of live and dead trees to capture the greatest possible number of fire scars. Multiple cross-sections were collected when additional scars were detected above or below cuts, or when decay precluded capturing all scars on a single crosssection. Locations of trees sampled were recorded using a GPS unit and measurements were taken of each sample's physical orientation with respect to aspect, slope, and height above ground level.

In the laboratory, cross-sections were surfaced using an electric planer, and the cellular detail of annual rings and fire-scar injuries was revealed by sanding with progressively finer sandpaper from ANSI 80 to 1200 grit. 
Two radii (outer to innermost tree-rings) of crosssections with the least ring-width variability and distortion were chosen for measurement. Tree-ring widths were measured to $0.01 \mathrm{~mm}$ precision using a Velmex Measuring System TA (Velmex, Inc., New York, New York, USA). Cross-dating was done through visual pattern matching of ring-width plots and anatomical features (Stokes and Smiley 1968), with statistical quality control performed using COFECHA software (Holmes 1983). Tree-ring dating of samples from HAG utilized the master ring-width chronology from the Wichita Mountains (Stambaugh et al. 2008), dating DPF samples utilized ring-width data from OKM (DeSantis et al. 2010a), and the HAG master chronology was used to date samples from TSH.

Innermost and outermost calendar years were recorded for each sample, along with the presence of pith or bark. Fire scars on both the lower and upper sample surfaces were identified based on the presence of charcoal, barrier zones, callus tissue, and cambial injury (Smith and Sutherland 2001), and assigned to the first year of growth response evident in the wound wood. Fire seasonality was determined for the majority of samples by evaluating the scar position within each annual growth ring. When fire scar positions were viewable, fire seasonality was classified as occurring in the earlywood (E), latewood (A), or dormant (D) ring positions (Kaye and Swetnam 1999). We assumed that growing-season fire scars (earlywood and latewood) were caused by events that occurred between approximately March and August, while dormant-season events occurred approximately between August and March. In some cases, firescar seasonality was classed as undeterminable (U) due to distortion or decay at the fire scar location within the sample. The time period of each sample and all fire-scar years and their seasonality were entered into the FHX and FHAES programs (Grissino-Mayer 2001; Brewer et al. 2017) to plot fire-scar chronologies and perform analyses of fire events by event characteristics (i.e., frequency, extent, severity, seasonality) and by time periods.

\section{Data analysis}

Fire-scar history data are spatially dependent (Falk et al. 2007; Stambaugh et al. 2016). Summary statistics were reported for study level $\left(\sim 1 \mathrm{~km}^{2}\right)$ and region level (all study sites combined, $\sim 140000 \mathrm{~km}^{2}$ ). At both scales, fire frequency, fire severity, and fire seasonality were quantified. Fire frequency was described using intervals (i.e., years) between subsequent fire event years. Mean fire intervals (MFIs) and Weibull median intervals (WMIs) were derived from the composite fire-scar chronology and represented the occurrence of fire somewhere in the study site area. WMIs were reported when KolmogorovSmirnov goodness of fit tests were significant, indicating that a Weibull distribution fit the fire interval distribution. Fire severity was calculated as the percentage of trees scarred in fire event years when sample depth was at least three trees. This assumption holds true in the absence of stand-replacing fires, for which there was no evidence (i.e., at each site, $>300$-year-old post oaks were present). Frequency distributions were used to describe fire severity by site, at the regional level, and by sub-period. Long-term trends in fire severity for the region were evaluated by calculating the mean percentage of trees scarred using a forward moving decadal average on a 1-year time step.

Fire frequency, severity, and seasonality were summarized for the entire periods of record and for three sub-periods corresponding to: pre Euro-American Settlement (EAS), post EAS, and recent use. For new study sites, calendar years corresponding to sub-periods were chosen based on local documented changes in land uses. For existing study sites, these periods were maintained from original publications. At DPF, fire-scar data were analyzed in a pre-EAS time period from 1704 to 1899 . This period was chosen because, although Native American populations in the area had fluctuated with both Osage and Creek settlements following the Indian Removal Act of 1830, the period following 1900 observed a development of further EAS influence via the incorporation of the nearby town of Oklmulgee and the establishment of Oklahoma's statehood (Okmulgee Historical Society and the Heritage Society of America 1985). The post-EAS period was from 1900 to 2016. At both HAG and TSH, the same periods of analysis were used as the sites are in close proximity (60 $\mathrm{km})$. For HAG, the pre-EAS period was 1707 to 1842 , while this period spans 1736 to 1842 at TSH. The postEAS period at both sites was from 1842 to 1946 , and the recent use period spanned 1946 to 2015, corresponding to establishment of the refuges.

A fire extent index (FEI; Guyette et al. 2002; Muzika et al. 2015) was calculated to evaluate regional fire extent across all sites. FEI provides an additional metric for understanding trends in fire extent by combining both regional and site data. Although fire scar history datasets are difficult to standardize, the FEI likely is more robust with large datasets that can reduce the effects of sample depth of sites and sample depth of trees within sites. FEI was calculated for each calendar year as the product of the number of sites that contained fire-scarred trees ( 0 to 13 , a value reflecting regional spatial extent of fire in a year) and the average percent of scarred trees across all sites (range $=0$ to 100 , a value reflecting the scale of fire severity). Fire extent and its 11-year moving average were then plotted through time.

\section{Results}

Site-level fire histories $\left(\sim 1 \mathrm{~km}^{2}\right)$

Samples from 148 trees were collected and dated across three new NWR study sites (Fig. 2). With the addition of 


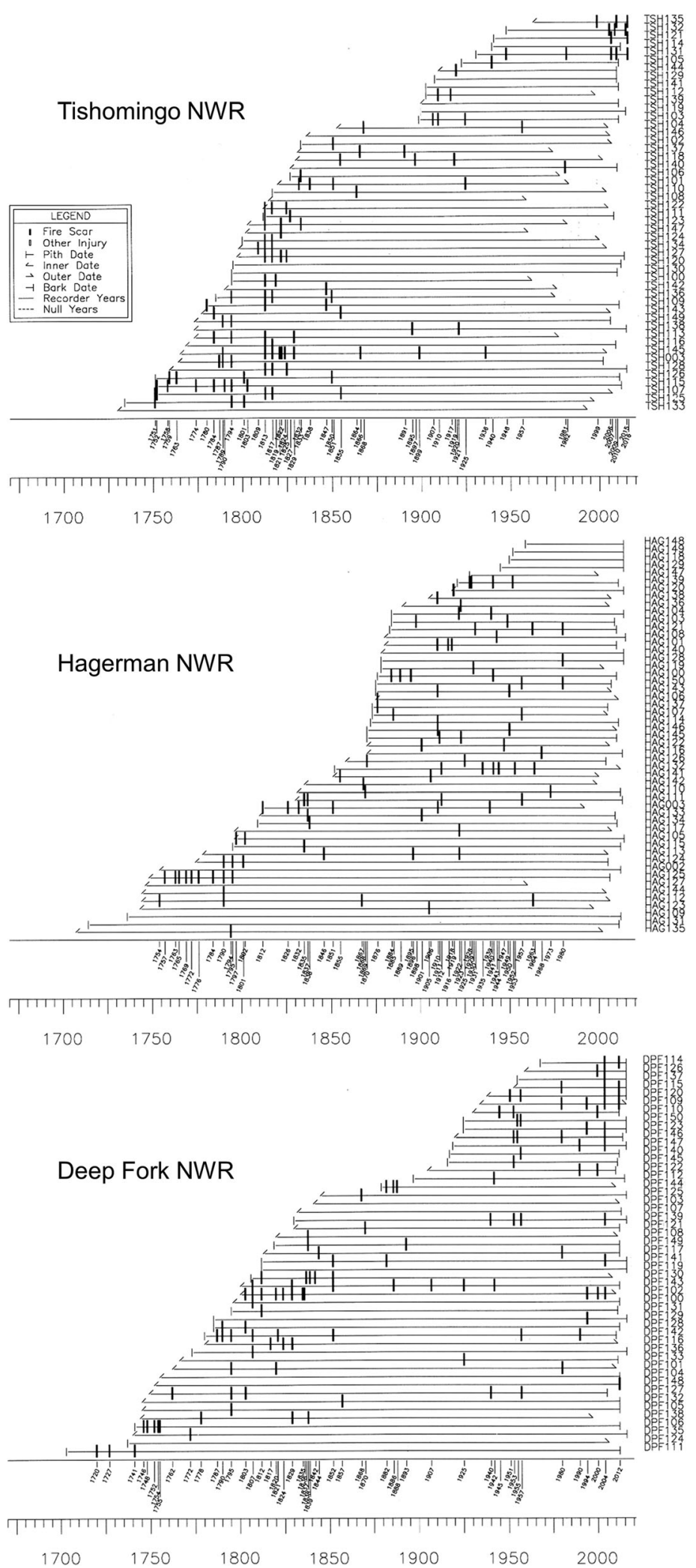

Fig. 2 New fire-scar history datasets for Tishomingo National Wildlife Refuge, Hagerman National Wildlife Refuge, and Deep Fork National Wildlife Refuge study sites of the south-central US prairie-forest transition zone, sampled in 2015 and 2016. Horizontal lines represent the periods of treering records for individual trees (sample numbers appear on far right side). Fire-scar dates are shown at bottom of chart with labeled dates 
existing regional fire history data, a total of 596 trees were represented across 13 study sites in the region (Table 1, Fig. 3). The maximum time period spanned by any site was 1636 to 2010 (374 years; CCH; Table 1). A common period of 1770 to 2002 (232 years) was shared across all 13 sites. In this common period, 223 fire events were recorded (222 fire intervals). The average number of fire intervals per site was 61 . The length of fire intervals ranged from 1 to 66 years, with the smallest range observed at HAG ( 1 to14 yr), and the largest range observed at $\mathrm{CCH}$ ( 1 to $66 \mathrm{yr}$, Table 2$)$. The average MFI for all sites was 5.1 years, calculated as an average of the MFIs across all 13 sites (Table 2). The shortest MFI for any site was at the TPP $(2.0 \mathrm{yr})$, while the longest MFI was observed at PRT (8.1 yr, Table 2). Low-severity fires (here defined as $\leq 5 \%$ trees scarred in a fire event) were the most common across all sites (Fig. 4). From the beginning of the recorded period, mean fire severity for the region has trended downward through time (Fig. 5).

In the pre-EAS period, the average number of fire intervals was 30 intervals per site. The length of fire intervals in this period ranged from 1 to $53 \mathrm{yr}$, with the smallest range observed at TSH ( 1 to $11 \mathrm{yr}$ ), and the largest range observed at $\mathrm{CCH}$ ( 1 to $53 \mathrm{yr}$; Table 2$)$. The average MFI for all sites in this period was $5.2 \mathrm{yr}$, calculated as an average of the MFIs across all 13 sites (Table 2). The shortest MFI for this time period was observed in northeastern Oklahoma at TLY (2.3 yr), while the longest MFI was observed in south-central Texas at BST (10.9 yr; Table 2).
In the post-EAS period, the average number of fire intervals was 22 intervals per site. The length of fire intervals in this period ranged from 1 to $66 \mathrm{yr}$, with the smallest range observed in northeastern Oklahoma at TLY ( 1 to $4 \mathrm{yr}$ ), and the largest range observed at $\mathrm{CCH}$ located in the Wichita Mountains of southwestern Oklahoma (2 to $66 \mathrm{yr}$; Table 2). The average MFI for all sites in this period was $6.8 \mathrm{yr}$, calculated as an average of the MFIs across all 13 sites (Table 2). The lowest MFI for this time period was observed in central Oklahoma at OKM (1.7 yr), while the highest MFI was observed at $\mathrm{CCH}$ located in the Wichita Mountains of in southwestern Oklahoma (19.3 yr; Table 2).

In the recent-use period, only six sites were included in this data stratification due to land use at the individual site level (Table 2). In this period, the average number of fire intervals was 15 intervals per site. The length of fire intervals in this period ranged from 1 to $30 \mathrm{yr}$ for all sites, with the smallest range observed in central Oklahoma at OKM ( 1 to 2 yr), and the largest range observed in south-central Oklahoma at TSH (1 to $24 \mathrm{yr}$, Table 2). The average MFI for all sites in this period was 5.1 years, calculated as an average of the MFIs across these six sites (Table 2). The lowest MFI for this time period was observed in north-central Oklahoma at TPP (1.3 yr), while the highest MFI was observed in northeastern Oklahoma at TLY (16.8 yr; Table 2).

In the common period (1770 to 2002), there were four years that recorded fire at eight of the 13 sites. The four years with the highest number of sites recording fire

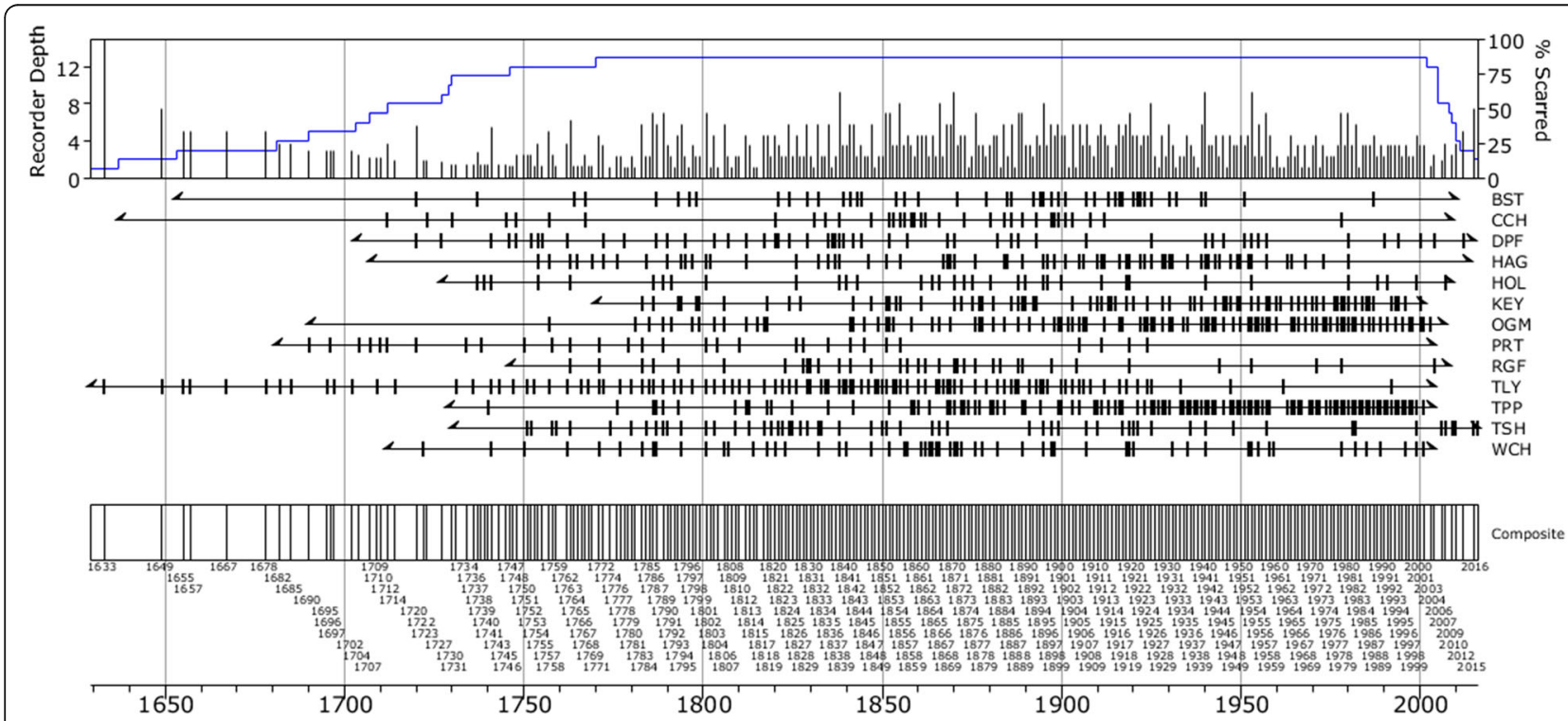

Fig. 3 Fire-scar records of 13 oak woodlands sites across the south-central US during the period 1636 to 2015 C.E. Horizontal lines represent the period of record of each site (i.e., all trees combined) with fire event years shown as bold vertical tick marks. Site codes (right) correspond to Table 1. Years at bottom represent the occurrence of fires across the study region. Top panel shows the number of sites represented through time (i.e., recorder depth, blue line) and the percentage of sites recording fire (percent scarred, vertical bars) 
Table 2 Summary statistics of fire-scar history data from the south-central US prairie-forest border region for the past three to four centuries. Scarred $($ mean \%) = average percentages of trees scarred during fire events, WMI = Weibull Median Interval (yr), MFI = Mean Fire Interval (yr), $\mathrm{n} / \mathrm{a}=$ data not available. Site codes are listed in Table 1 (Continued on next page)

\begin{tabular}{|c|c|c|c|c|c|c|c|c|c|c|}
\hline \multicolumn{11}{|c|}{ All years } \\
\hline \multirow[b]{2}{*}{ Site } & \multirow[b]{2}{*}{ Years } & \multirow{2}{*}{$\begin{array}{r}\text { Scars } \\
(n)\end{array}$} & \multirow{2}{*}{$\begin{array}{r}\text { Fire intervals } \\
(n)\end{array}$} & \multirow{2}{*}{$\begin{array}{l}\text { MFI } \\
(y r)\end{array}$} & \multirow{2}{*}{$\begin{array}{r}\text { Range } \\
(y r)\end{array}$} & \multirow{2}{*}{$\begin{array}{r}\text { WMI } \\
(\mathrm{yr})\end{array}$} & \multirow{2}{*}{$\begin{array}{r}\text { Scarred } \\
\text { (mean \%) }\end{array}$} & \multicolumn{3}{|l|}{ Season \% } \\
\hline & & & & & & & & Dormant & Growing & Undetermined \\
\hline$\overline{\mathrm{BST}}$ & $1653-2011$ & 98 & 45 & 5.93 & $1-36$ & 3.96 & 7 & 58 & 21 & 20 \\
\hline $\mathrm{CCH}$ & 1636-2009 & 91 & 34 & 7.94 & $1-66$ & 4.5 & 12 & 97 & 2 & 1 \\
\hline DPF & 1703-2016 & 115 & 49 & 5.53 & $1-23$ & 4.56 & 13 & 89 & 3 & 9 \\
\hline WCH & $1712-2005$ & 122 & 59 & 7.82 & $1-19$ & 3.77 & 6 & 78 & 2 & 20 \\
\hline HAG & 1707-2015 & 92 & 66 & 3.42 & $1-14$ & 2.87 & 6 & 71 & 4 & 25 \\
\hline $\mathrm{HOL}$ & $1720-2009$ & 105 & 34 & 7.09 & $1-27$ & 6.14 & 10 & 88 & 0 & 12 \\
\hline KEY & 1770-2002 & 138 & 76 & 2.86 & $1-15$ & 2.35 & 10 & 68 & 20 & 12 \\
\hline TLY & 1646-2005 & 205 & 101 & 3.4 & $1-30$ & 2.63 & 5 & 90 & 4 & 6 \\
\hline OKM & 1742-2008 & 172 & 95 & 2.59 & $1-24$ & 1.98 & 3 & 60 & 3 & 36 \\
\hline PRT & $1691-2005$ & 83 & 29 & 8.07 & $2-50$ & 6.56 & 11 & 93 & 0 & 7 \\
\hline RGF & 1746-2008 & 102 & 34 & 4.73 & $1-26$ & 5.53 & 12 & 80 & 6 & 14 \\
\hline TPP & 1729-2005 & 242 & 111 & 2.03 & $1-16$ & 1.59 & 6 & 69 & 20 & 11 \\
\hline TSH & 1730-2016 & 112 & 57 & 4.65 & $1-24$ & 4.68 & 11 & 87 & 3 & 11 \\
\hline \multicolumn{11}{|c|}{ Pre European-American settlement } \\
\hline BST & $1653-1829$ & 30 & 45 & 10.9 & $2-27$ & 8.41 & 11 & 58 & 16 & 26 \\
\hline $\mathrm{CCH}$ & 1637-1899 & 35 & 34 & 6.45 & $1-53$ & 4.25 & 12 & 97 & 1 & 1 \\
\hline DPF & 1704-1899 & 34 & 49 & 4.47 & $1-12$ & 3.95 & 9 & 73 & 5 & 22 \\
\hline WCH & 1712-1899 & 52 & 59 & 4.4 & $1-19$ & 3.56 & 8 & 76 & 2 & 22 \\
\hline HAG & 1707-1842 & 20 & 66 & 4.42 & $1-14$ & 3.82 & 13 & 42 & 6 & 52 \\
\hline $\mathrm{HOL}$ & 1720-1899 & 33 & 34 & 6.91 & $1-25$ & 5.19 & 15 & 87 & 0 & 13 \\
\hline KEY & 1772-1907 & 51 & 76 & 4.14 & $1-15$ & 3.33 & 15 & 71 & 15 & 15 \\
\hline TLY & 1650-1889 & 29 & 101 & 2.95 & $1-17$ & 2.51 & 13 & 91 & 3 & 6 \\
\hline OKM & 1750-1899 & 62 & 95 & 4.3 & $1-24$ & 3.23 & 3 & 70 & 5 & 25 \\
\hline PRT & 1690-1820 & 28 & 29 & 6.67 & $2-14$ & 6.37 & 16 & 88 & 0 & 12 \\
\hline RGF & 1746-1899 & 38 & 34 & 4.96 & $1-17$ & 4.16 & 13 & 80 & 5 & 15 \\
\hline TPP & 1770-1871 & 54 & 111 & 3.5 & $1-16$ & 3.65 & 11 & 50 & 8 & 42 \\
\hline TSH & 1736-1842 & 35 & 57 & 3.35 & $1-11$ & 2.95 & 16 & 82 & 3 & 15 \\
\hline \multicolumn{11}{|c|}{ Post European-American settlement } \\
\hline BST & 1830-1940 & 75 & 32 & 3.38 & $1-11$ & 2.8 & 5 & 57 & 25 & 20 \\
\hline $\mathrm{CCH}$ & $1901-2010$ & 20 & 4 & 19.25 & $2-66$ & 8.71 & 11 & 95 & 5 & 0 \\
\hline DPF & 1900-2016 & 81 & 14 & 7.5 & $2-23$ & 6.04 & 9 & 89 & 0 & 11 \\
\hline WCH & 1901-2005 & 35 & 18 & 5.22 & $1-19$ & 4.04 & 4 & 83 & 3 & 14 \\
\hline HAG & 1842-1946 & 49 & 35 & 2.8 & $1-12$ & 2.31 & 4 & 76 & 2 & 22 \\
\hline $\mathrm{HOL}$ & $1901-2010$ & 48 & 9 & 10.67 & $1-27$ & 8.85 & 11 & 88 & 0 & 13 \\
\hline KEY & 1908-2001 & 97 & 46 & 2 & $1-6$ & 1.86 & 8 & 67 & 23 & 10 \\
\hline TLY & 1890-1925 & 24 & 16 & 2.12 & $1-4$ & 2.02 & 19 & 88 & 13 & 0 \\
\hline OKM & 1900-1988 & 132 & 52 & 1.67 & $1-5$ & 1.54 & 3 & 58 & 2 & 39 \\
\hline PRT & 1820-1924 & 33 & 10 & 9.8 & $2-50$ & 6.78 & 9 & 100 & 0 & 0 \\
\hline RGF & 1901-2009 & 23 & 6 & 16.67 & $7-26$ & 16.33 & 9 & 83 & 9 & 9 \\
\hline TPP & 1871-1914 & 23 & 19 & 2.16 & $1-5$ & 2.18 & 4 & 65 & 4 & 30 \\
\hline TSH & 1842-1946 & 63 & 19 & 4.89 & $1-23$ & 3.75 & 4 & 87 & 3 & 10 \\
\hline
\end{tabular}


Table 2 Summary statistics of fire-scar history data from the south-central US prairie-forest border region for the past three to four centuries. Scarred (mean \%) = average percentages of trees scarred during fire events, WMI = Weibull Median Interval (yr), MFI = Mean Fire Interval (yr), $\mathrm{n} / \mathrm{a}=$ data not available. Site codes are listed in Table 1 (Continued)

\begin{tabular}{|c|c|c|c|c|c|c|c|c|c|c|}
\hline \multicolumn{11}{|c|}{ All years } \\
\hline \multirow[b]{2}{*}{ Site } & \multirow[b]{2}{*}{ Years } & \multirow{2}{*}{$\begin{array}{r}\text { Scars } \\
(n)\end{array}$} & \multirow{2}{*}{$\begin{array}{r}\text { Fire intervals } \\
(n)\end{array}$} & \multirow{2}{*}{$\begin{array}{l}\text { MFI } \\
(\mathrm{yr})\end{array}$} & \multirow{2}{*}{$\begin{array}{r}\text { Range } \\
(y r)\end{array}$} & \multirow{2}{*}{$\begin{array}{r}\text { WMI } \\
(\mathrm{yr})\end{array}$} & \multirow{2}{*}{$\begin{array}{r}\text { Scarred } \\
\text { (mean \%) }\end{array}$} & \multicolumn{3}{|l|}{ Season \% } \\
\hline & & & & & & & & Dormant & Growing & Undetermined \\
\hline \multicolumn{11}{|c|}{ Recent use } \\
\hline BST & $1941-2011$ & 4 & 1 & $\mathrm{n} / \mathrm{a}$ & $\mathrm{n} / \mathrm{a}$ & $\mathrm{n} / \mathrm{a}$ & 4 & 75 & 25 & 0 \\
\hline $\mathrm{CCH}$ & $\mathrm{n} / \mathrm{a}$ & $\mathrm{n} / \mathrm{a}$ & $\mathrm{n} / \mathrm{a}$ & $\mathrm{n} / \mathrm{a}$ & $\mathrm{n} / \mathrm{a}$ & $\mathrm{n} / \mathrm{a}$ & $\mathrm{n} / \mathrm{a}$ & $\mathrm{n} / \mathrm{a}$ & $\mathrm{n} / \mathrm{a}$ & $n / a$ \\
\hline DPF & $\mathrm{n} / \mathrm{a}$ & $\mathrm{n} / \mathrm{a}$ & $\mathrm{n} / \mathrm{a}$ & $\mathrm{n} / \mathrm{a}$ & $\mathrm{n} / \mathrm{a}$ & $\mathrm{n} / \mathrm{a}$ & $\mathrm{n} / \mathrm{a}$ & $\mathrm{n} / \mathrm{a}$ & $\mathrm{n} / \mathrm{a}$ & $n / a$ \\
\hline WCH & $\mathrm{n} / \mathrm{a}$ & $\mathrm{n} / \mathrm{a}$ & $\mathrm{n} / \mathrm{a}$ & $\mathrm{n} / \mathrm{a}$ & $\mathrm{n} / \mathrm{a}$ & $\mathrm{n} / \mathrm{a}$ & $\mathrm{n} / \mathrm{a}$ & $\mathrm{n} / \mathrm{a}$ & $\mathrm{n} / \mathrm{a}$ & $\mathrm{n} / \mathrm{a}$ \\
\hline HAG & 1946-2015 & 17 & 10 & 3.3 & $1-7$ & 2.95 & 3 & 82 & 6 & 12 \\
\hline $\mathrm{HOL}$ & $\mathrm{n} / \mathrm{a}$ & $\mathrm{n} / \mathrm{a}$ & $n / a$ & $n / a$ & $\mathrm{n} / \mathrm{a}$ & $\mathrm{n} / \mathrm{a}$ & $\mathrm{n} / \mathrm{a}$ & $\mathrm{n} / \mathrm{a}$ & $\mathrm{n} / \mathrm{a}$ & $n / a$ \\
\hline KEY & $\mathrm{n} / \mathrm{a}$ & $\mathrm{n} / \mathrm{a}$ & $\mathrm{n} / \mathrm{a}$ & $\mathrm{n} / \mathrm{a}$ & $\mathrm{n} / \mathrm{a}$ & $\mathrm{n} / \mathrm{a}$ & $\mathrm{n} / \mathrm{a}$ & $\mathrm{n} / \mathrm{a}$ & $\mathrm{n} / \mathrm{a}$ & $\mathrm{n} / \mathrm{a}$ \\
\hline TLY & 1925-1992 & 7 & 4 & 16.75 & $8-30$ & 16.14 & 58 & 86 & 0 & 14 \\
\hline OKM & 1989-2005 & 25 & 8 & 1.75 & $1-2$ & 1.79 & 4 & 68 & 0 & 32 \\
\hline PRT & $\mathrm{n} / \mathrm{a}$ & $\mathrm{n} / \mathrm{a}$ & $\mathrm{n} / \mathrm{a}$ & $\mathrm{n} / \mathrm{a}$ & $\mathrm{n} / \mathrm{a}$ & $\mathrm{n} / \mathrm{a}$ & $\mathrm{n} / \mathrm{a}$ & $\mathrm{n} / \mathrm{a}$ & $\mathrm{n} / \mathrm{a}$ & $\mathrm{n} / \mathrm{a}$ \\
\hline RGF & $\mathrm{n} / \mathrm{a}$ & $\mathrm{n} / \mathrm{a}$ & $\mathrm{n} / \mathrm{a}$ & $\mathrm{n} / \mathrm{a}$ & $\mathrm{n} / \mathrm{a}$ & $\mathrm{n} / \mathrm{a}$ & $\mathrm{n} / \mathrm{a}$ & $\mathrm{n} / \mathrm{a}$ & $\mathrm{n} / \mathrm{a}$ & $\mathrm{n} / \mathrm{a}$ \\
\hline TPP & 1915-1989 & 194 & 59 & 1.25 & $1-5$ & 1.17 & 6 & 72 & 23 & 5 \\
\hline $\mathrm{TSH}$ & 1946-2015 & 17 & 9 & 7.44 & $1-24$ & 4.88 & 7 & 100 & 0 & 0 \\
\hline
\end{tabular}

events were 1838, 1870, 1940, and 1953. Fire frequency results were not consistent across all 13 sites. The four northern-most study sites (TPP, KEY, TLY, OKM) experienced an increase in fire frequency following EAS (Table 2). South of OKM, a grouping of study sites recorded less fire than more northerly sites during the post-EAS period (DPF, TSH, CCH, HOL, RGF, and WCH). Farther south into Texas, post-EAS changes in fire frequency were mixed with both HAG and BST experiencing increased fire frequency, while PRT experienced decreased fire frequency. Both PRT and BST experienced a long duration of fire suppression in the latter part of the twentieth century (Stambaugh et al. 2011; Stambaugh et al. 2017b).

All sites were dominated by dormant-season fires. Percentages of dormant season fires at sites ranged from 58 to $97 \%$ across all years (Table 2). By comparison, growingseason fires ranged from 0 to $21 \%$ (Table 2). BST, the southern-most site, recorded more growing-season fires than any other site, with $21 \%$ of the fire scars there recorded during the growing season (Table 2). Among all sites, fire-scar seasonality was undetermined for a range of 1 to $36 \%$ of fire scars.

\section{Regional fire history $\left(\sim 140000 \mathrm{~km}^{2}\right)$}

Fire events were two to seven times more frequent when considered at a regional level compared to site level (Table 2). Only 10 years without fire occurred during the common period (1770 to 2002), resulting in a regional
MFI of 1.04 years (range $=1$ to $2 \mathrm{yr}$, Fig. 3 ). In the preEAS period (1770 to 1877), the MFI was 1.08 years (range $=1$ to $2 \mathrm{yr}$ ). During the post-EAS period, fire was most frequent with a MFI of $1.0 \mathrm{yr}$.

Fire interval lengths have trended generally downward through time, with a period of regionally shortened intervals observed between approximately 1850 to 1900 (Fig. 3). One-year intervals occurred most frequently among all sites, while longer intervals were much less common. When considering all years as well as only the post-EAS period, the majority of fire events were recorded on 1 to $5 \%$ of trees (Fig. 4). In both the pre-EAS period and in the recent-use period, the majority of fire events were recorded on 6 to $10 \%$ of trees (Fig. 4). The FEI and its 11-year moving average were used to evaluate the extent of fire events at the regional level across all 13 sites. For the common period for all sites (1770 to 2002), FEI trended upward until the mid-nineteenth century, after which it stabilized and then began to decline circa 1910 to 1920 (Fig. 5). The years 1838, 1870, 1940, and 1953 had the highest FEI, when eight sites recorded fire.

\section{Discussion}

The oak-dominated ecosystems across the south-central US are of special interest due to their antiquity and extent, evidence for frequent historical fire regimes, and ecological and societal values (Anderson 2006). In this prairie-forest transitional region, fire regimes and associated effects of fire on vegetation composition and structure are still 

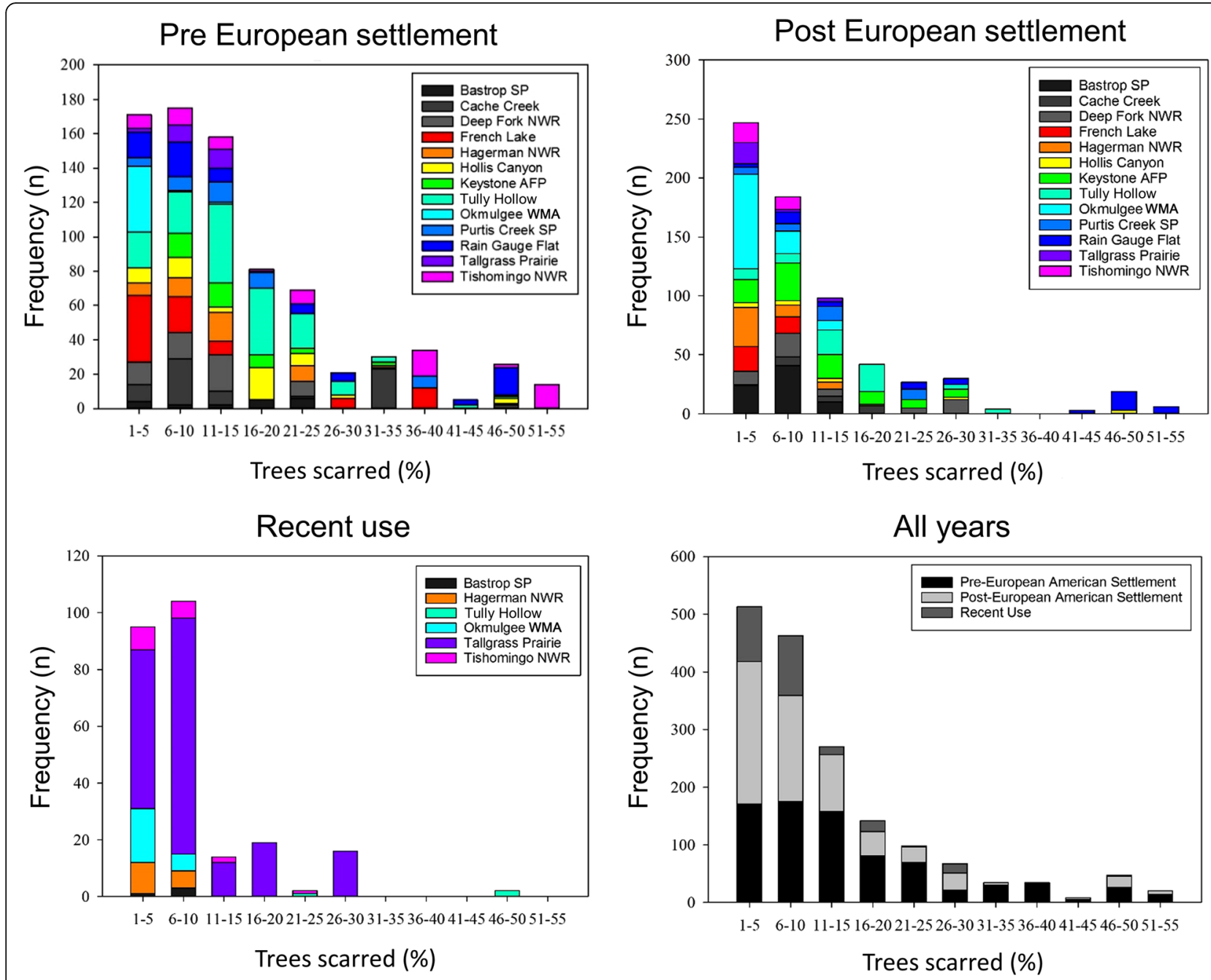

Fig. 4 Frequency distributions of percentages of trees across south-central US oak woodlands during the period 1636 to 2015 C.E. Data are stratified by three time periods and compiled for all sites in all years. SP $=$ State Park, AFP $=$ Ancient Forest Preserve, NWR $=$ National Wildlife Refuge, WMA = Wildlife Management Area

being defined. Human interactions with fire and vegetation appear to have varied with human population density and culture (Guyette et al. 2002; Clark et al. 2007; DeSantis et al. 2010b; Stambaugh et al. 2014). Findings here suggest that, while fire frequency increased following EAS, fire severity trended lower, possibly due to increased fuel-fragmentation and land-use changes across the region.

Differences in site fire histories existed across the region. The four most northern sites in Oklahoma (TPP, KEY, TLY, OKM; Table 1) underwent an increase in fire frequency following EAS, while Oklahoma sites to the south (DPF, TSH, CCH, HOL, RGF, WCH) all observed a decrease in fire frequency following EAS. In Texas, changes in fire frequency at the three study sites were variable, with PRT undergoing a decrease in fire following EAS, and HAG and
BST observing an increase in fire frequency following EAS. With sites in close geographic proximity exhibiting comparable fire regime trends, the findings suggest sub-regional relationships between fire regime changes and geography.

At TPP in northern Oklahoma, there is evidence of historical burning by cattle producers as early as 1923 (Hensel 1923). Similar management has continued at TPP until the present day (Allen and Palmer 2011) and is common across a larger geography (e.g., Flint Hills of Kansas). At OKM, there is evidence that an increase in human occupation after 1900 at the site initiated more frequent burning (DeSantis et al. 2010b). At KEY in north-central Oklahoma, the increased fire frequency was attributed to an increased population following statehood due to increased human population density (Clark et al. 2007). 


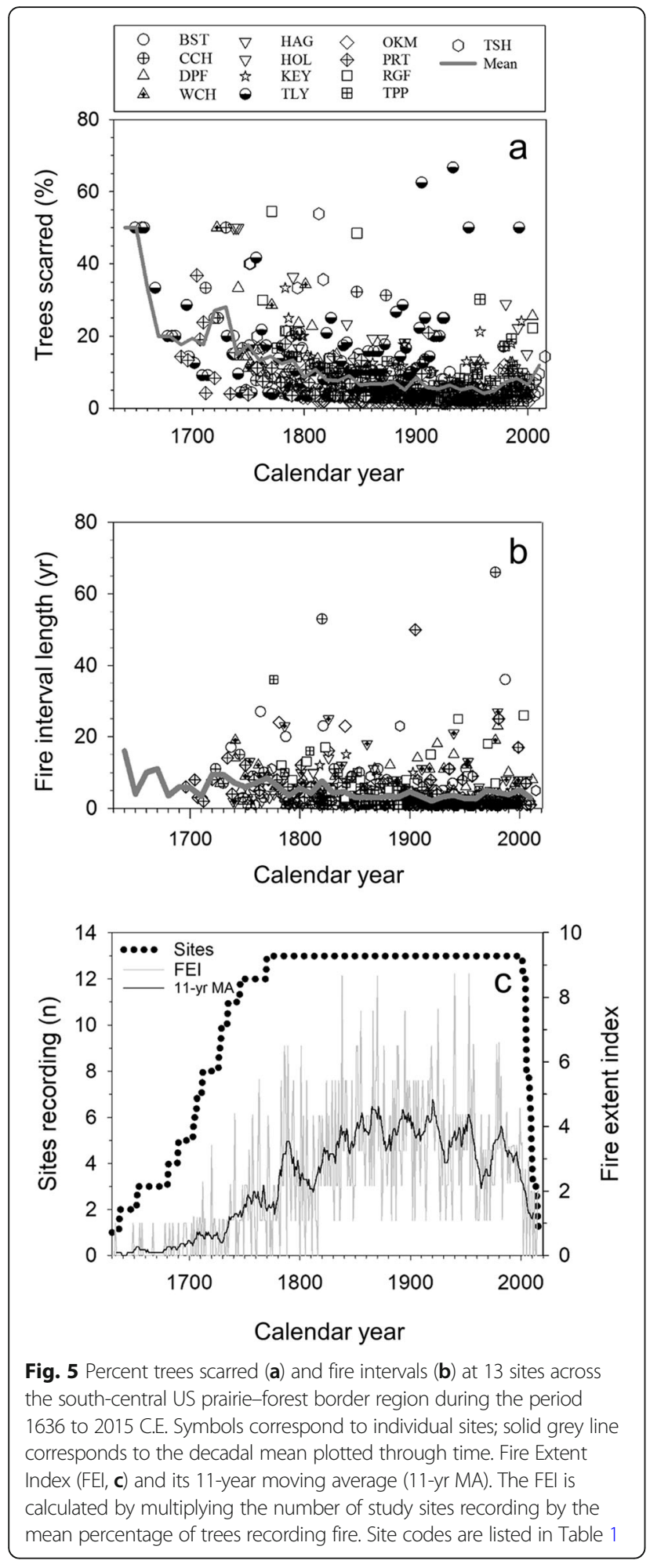

Fire history sites at both TSH and all sites within the Wichita Mountains are in close proximity to forts established by the US government. Fort Washita, $8 \mathrm{~km}$ from TSH (established in 1842), and Fort Sill, $30 \mathrm{~km}$ from Wichita Mountains NWR (established 1869), were both hubs of human activity, and their establishment led to increased human occupation and grazing in the vicinity (Wittry 1961; National Register Properties in Oklahoma 2017). Based on the data presented here, fire occurrence decreased following the establishment of these forts. Grazing has known impacts on fuel reduction and fuel fragmentation. Human developments such as roads, railroads, state borders, divisions of public and private lands, and passageways for domesticated livestock all contribute to the division and fragmentation of fire regimes and fuels. Guyette et al. (2002) identified "fuel fragmentation" as a predictable stage of an anthropogenic fire regime whereby human (and animal) density and land conversion is negatively related to fire frequency. For rangelands, concern for losses of animal forage can encourage fire suppression (Touchan et al. 1995; Courtwright 2007) and may be one explanation for a decrease in fire frequency at the southern Oklahoma sites. The inconsistency in fire occurrence findings at Texas sites may also be influenced by a history of grazing in the state, although the geographic relationship between Texas sites is less apparent. At BST, EAS included increases in human populations and open-range grazing (Stambaugh et al. 2017b), although no history of grazing is known at either HAG or PRT besides being within an extensive network of cattle drive trails associated with the Chisholm and Shawnee trails.

While frequency of fire at the regional level increased following EAS, fire severity decreased across the region. TPP, KEY, and all sites in the Wichita Mountains exhibited lower percentages of trees scarred in the post-EAS period than in the pre-EAS period (Clark et al. 2007; Stambaugh et al. 2009; Allen and Palmer 2011). This result may indicate that there has been a restriction on fire's ability to spread during this period. Alternatively, this result could indicate that these fires burned through fine fuels, which tend to be fires of shorter duration and potentially scar fewer trees in comparison to longerduration fires that burn through woody fuels (McArthur and Cheney 2015). Previous results from the Cross Timbers region also suggest that land use in the region influenced fire severity (Clark et al. 2007; DeSantis et al. 2010b; Allen and Palmer 2011). High frequency of burning or grazing would have reduced fuel loads and reaccumulation of fuels, resulting in decreasing fire spread and duration.

The FEI portrayed a varying extent of fire at the regional level across all 13 sites. Eighty-six percent of fire years in the common period between all sites (1770 to 2002) were shared between at least two sites, although the geographic relationship between shared fire years was not considered. Stambaugh et al. (2013) previously showed that fire years at TLY were synchronous with those in the central and western Ozark region of 
Arkansas and Missouri (Guyette et al. 2006). Regional fire synchrony was attributed to drought conditions and a similarity in anthropogenic influences and their timing. The prairie-forest border region is an extension of these data west and southward; therefore, it may be assumed that the high congruence of fire years between some sites suggests a similar relationship. However, with the transition to the Great Plains, further examination of these drivers, including the likely influence of grazing, is warranted.

The results of this study indicate a historical prevalence of dormant-season fires in the region. The primary lightning season is during the summer growing season (Holle and Cummins 2010) and the low occurrence of growing-season fires suggests that lightning has not been the primary ignition source. A possible exception is at BST where $21 \%$ of fire scars were recorded in the growing season. BST is the southern-most site, where growing seasons, and potentially fire seasons, are longer than at other sites in this study (Stambaugh et al. 2017b). Future fire-scar history research in more southerly locations of the prairie-forest border will likely be useful for refining fire seasonality and attributing fires to lightning versus human ignitions.

\section{Conclusions}

Many natural resource management efforts rely on scientific studies for their justification and design. Historical fire regime data can inform vegetation management where historical conditions or processes remain relevant (Swetnam et al. 1999). Prescribed and wildfire management occur over hundreds to thousands of hectares in the south-central US annually. Long-term fire history records may aid in evaluating spatial and temporal patterns in fire occurrence and guide fire management strategies accordingly. Modern policies focus ecosystem restoration efforts on prescribed burning and fuel reduction on millions of hectares and have proposed management for pre-fire suppression-era fire regimes (Wildland Fire Leadership Council 2014). The data presented here provide the first multi-century and quantitative synthesis of fire regimes along the south-central US prairie-forest border, a transition zone with vegetation characteristics often attributed to a historical legacy of fire. Our findings emphasize the extensive and relatively frequent occurrence of fire in historical times, particularly during the dormant season. This network of sites contributes to a paucity of information needed to define eastern US fire regimes, and suggests features perhaps unique to the south-central US.

\section{Acknowledgements}

This research was supported in the field and laboratory by J. Marschall, R. Guyette, E. Abadir, A. Kestermont, and S. Kosark. Fieldwork logistical support was provided by US Fish and Wildlife Service National Wildlife Refuge staff located throughout Oklahoma and Texas. Additional acknowledgement to S. Clark, R. DeSantis, and M. Allen for contributing their fire-scar history data to this analysis.

\section{Authors' contributions}

MR provided a major contribution to data collection and data analyses. MS provided a major contribution to securing funding support, and study conception and design. Both authors contributed to writing the manuscript and approved the final version submitted.

\section{Funding}

The research was funded by the US Fish and Wildlife Service, Award \# F14AC00680.

\section{Availability of data and materials}

The datasets used or analyzed during the current study are available from the corresponding author on reasonable request.

Ethics approval and consent to participate

Not applicable.

Consent for publication

Not applicable.

\section{Competing interests}

The authors declare that they have no competing interests.

Received: 29 November 2018 Accepted: 22 May 2019

Published online: 25 July 2019

\section{References}

Allen, M.S., and M.W. Palmer. 2011. Fire history of a prairie/forest boundary: more than 250 years of frequent fire in a North American tallgrass prairie. Journal of Vegetation Science 22: 436-444 https://doi.org/10.1111/j.1654-1103.2011.01278.x.

Anderson, R.C. 2006. Evolution and the origin of the central grassland of North America: climate, fire, and mammalian grazers. Journal of the Torrey Botanical Society 133: 626-647 https://doi.org/10.3159/10955674(2006)133[626:EAOOTC]2.0.CO;2.

Batek, M.J., A.J. Rebertus, W.A. Schroeder, T.L. Haithcoat, E. Compas, and R.P. Guyette. 1999. Reconstruction of early nineteenth-century vegetation and fire regimes in the Missouri Ozarks. Journal of Biogeography 26: 397-412 https:// doi.org/10.1046/j.1365-2699.1999.00292.x.

Brewer, P.W., M.E. Velásquez, E.K. Sutherland, and D.A. Falk. 2017. FHAES: Fire History Analysis and Exploration System. Version 2.0.2. https://www.frames. gov/fhaes/home. Accessed 13 May 2019.

Clark, S.L., S.W. Hallgren, D.M. Engle, and D.W. Stahle. 2007. The historic fire regime of the edge of the prairie: a case study from the Cross Timbers of Oklahoma. Proceedings of the Tall Timbers Fire Ecology Conference 23: 40-49.

Courtwright, J.R. 2007. Taming the red buffalo: prairie fire on the Great Plains. Fayetteville: Dissertation, University of Arkansas.

DeSantis, R.D., S.W. Hallgren, and D.W. Stahle. 2010a. Tree ring data, post oak. Okmulgee Game Management Area, Oklahoma. (OK035). International TreeRing Data Bank. http://www.ncdc.noaa.gov/paleo/treering.html. Accessed 9 Mar 2016.

DeSantis, R.D., S.W. Hallgren, and D.W. Stahle. 2010b. Historic fire regime of an upland oak forest in south-central North America. Fire Ecology 6: 45-61.

DeSantis, R.D., S.W. Hallgren, and D.W. Stahle. 2011. Drought and fire suppression lead to rapid forest composition change in a forest-prairie ecotone. Forest Ecology and Management 261: 1833-1840.

Falk, D.A., C. Miller, D. McKenzie, and A.E. Black. 2007. Cross-scale analysis of fire regimes. Ecosystems 10: 809-823.

Falk, D.A., and T.W. Swetnam. 2003. Scaling rules and probability models for surface fire regimes in ponderosa pine forests. In Fire ecology, fuel treatments, and ecological restoration. USDA Forest Service General Technical Report RMRSP-29, ed. P.N. Omi and L.A. Joyce, 301-317. Fort Collins: USDA Forest Service, Rocky Mountain Research Station.

Grissino-Mayer, H.D. 2001. FHX2-software for analyzing temporal and spatial patterns in fire regimes from tree rings. Tree-Ring Research 57: 115-124.

Guyette, R.P., R.-M. Muzika, and D.C. Dey. 2002. Dynamics of an anthropogenic fire regime. Ecosystems 5 (5): 472-486. 
Guyette, R.P., M.A. Spetich, and M.C. Stambaugh. 2006. Historic fire regime dynamics and forcing factors in the Boston Mountains, Arkansas, USA. Forest Ecology and Management 234: 293-304 https://doi.org/10.1016/j.foreco.2006.07.016.

Guyette, R.P., and M.C. Stambaugh. 2004. Post oak fire scars as a function of diameter, growth, and tree age. Forest Ecology and Management 198: 183-192 https://doi.org/10.1016/j.foreco.2004.04.016.

Guyette, R.P., M.C. Stambaugh, D.C. Dey, and R.-M. Muzika. 2012. Estimating fire frequency with the chemistry and climate. Ecosystems 15: 322-335 https:// doi.org/10.1007/s10021-011-9512-0.

Hanberry, B.B., J.M. Kabrick, and H.S. He. 2014. Densification and state transition across the Missouri Ozarks landscape. Ecosystems 17: 66-81 https://doi.org/10. 1007/s10021-013-9707-7.

Hensel, R.L. 1923. Recent studies on the effect of burning on grassland vegetation. Ecology 4: 183-188 https://doi.org/10.2307/1929492.

Hoagland, B.W., I.H. Butler, F.L. Johnson, and S. Glenn. 1999. The Cross Timbers: savannas, barrens, and rock outcrop plant communities of North America. In Savannas, barrens, and rock outcrop plant communities of North America, ed. R.C. Anderson, J.S. Fralish, and J.M. Baskin, 231-245. New York: Cambridge University Press https://doi.org/10.1017/ CBO9780511574627.015.

Holle, R.L., and K.L. Cummins. 2010. Monthly distributions of US NLDN cloud-toground lightning. Preprints, International Lightning Meteorology Conference, 21 22 April 2010. Orlando, Florida. Tucson, Arizona, USA: Vaisala.

Holmes, R.L. 1983. Computer assisted quality control in tree-ring dating and measurement. Tree-Ring Bulletin 43: 69-78.

Johnson, P.S., S.R. Shifley, and R. Rogers. 2009. The ecology and silviculture of oaks. 2nd ed. Cambridge: CAB International https://doi.org/10.1079/9781845934743.0000.

Jones, R.A., J.W. Williams, and S.T. Jackson. 2017. Vegetation history since the last glacial maximum in the Ozark highlands (USA): a new record from Cupola Pond, Missouri. Quaternary Science Reviews 170: 174-187 https://doi.org/10. 1016/j.quascirev.2017.06.024

Kaye, M.W., and T.W. Swetnam. 1999. An assessment of fire, climate and Apache history in the Sacramento Mountains, New Mexico. Physical Geography 20: 305-330 https://doi.org/10.1080/02723646.1999.10642681.

Kuchler, A.W. 1964. Potential natural vegetation of the coterminous United States. Special publication 36. Washington, D.C.: American Geographical Society.

Lafon, C.W., A.T. Naito, H.D. Grissino-Mayer, S.P. Horn, and T.A. Waldrop. 2017. Fire history of the Appalachian region: a review and synthesis. USDA Forest Service General Technical Report SRS-219. Asheville: USDA Forest Service, Southern Research Station.

McArthur, A.G., and N.P. Cheney. 2015. The characterization of fire in relation to ecological studies. Fire Ecology 11 (1): 3-9 https://doi.org/10.1007/BF03400629.

Moore, C.T. 1972. Man and fire in the central North American grassland 15351890: a documentary historical geography. Los Angeles: Dissertation, University of California.

Muzika, R.-M., R.P. Guyette, M.C. Stambaugh, and J.M. Marschall. 2015. Fire, drought, and humans in a heterogeneous Lake Superior landscape. Journal of Sustainable Forestry 34: 49-70 https://doi.org/10.1080/10549811.2014.973991.

National Register Properties in Oklahoma. 2017. Complete national register site documentation, Fort Washita, OK. http://nr2_shpo.okstate.edu/QueryResult. aspx?id=66000626. Accessed 19 May 2019.

Okmulgee Historical Society and the Heritage Society of America. 1985. History of Okmulgee County, Oklahoma. Volume 1. Tulsa: Historical Enterprises.

Omernik, J.M. 1987. Ecoregions of the coterminous United States. Annals of the American Association of Geographers 77 (1): 118-125 https://doi.org/10.1111/j. 1467-8306.1987.tb00149.x

Rice, E.L., and W.T. Penfound. 1959. The upland forests of Oklahoma. Ecology 40: 593-608 https://doi.org/10.2307/1929813.

Runkle, J., K. Kunkel, J. Nielsen-Gammon, R. Frankson, S. Champion, B. Stewart, L. Romolo, and W. Sweet. 2017. Texas State climate summary. NOAA Technical Report NESDIS 149-TX. Asheville: North Carolina Institute for Climate Studies.

Scasta, J.D., J.R. Weir, and M.C. Stambaugh. 2016. Droughts and wildfires in western US rangelands. Rangelands 38: 197-203 https://doi.org/10.1016/j.rala.2016.06.003.

Smith, K.T., and E.K. Sutherland. 2001. Terminology and biology of fire scars in selected central hardwoods. Tree-Ring Research 57: 141-147.

Soil Survey Staff. 2009. Web soil survey. Natural Resources Conservation Service, United States Department of Agriculture. http://websoilsurvey.nrcs.usda.gov. Accessed 15 Dec 2016.

Spearing, D. 1991. Roadside geology of Texas. Missoula: Mountain Press Publishing.
Stambaugh, M.C., G. Creacy, J. Sparks, and M. Rooney. 2017b. Three centuries of fire and forest vegetation transitions preceding Texas' most destructive wildfire: Lost Pines or lost oaks? Forest Ecology and Management 396: 91-101 https://doi.org/10.1016/j.foreco.2017.04.017.

Stambaugh, M.C., and R.P. Guyette. 2008. Predicting spatio-temporal variability in fire return intervals using a topographic roughness index. Forest Ecology and Management 254: 463-473 https://doi.org/10.1016/j. foreco.2007.08.029.

Stambaugh, M.C., R.P. Guyette, R. Godfrey, E.R. McMurry, and J.M. Marschall. 2009. Fire, drought, and human history near the western terminus of the Cross Timbers, Wichita Mountains, Oklahoma. Fire Ecology 5 (2): 51-65 https://doi. org/10.4996/fireecology.0502051.

Stambaugh, M.C., R.P. Guyette, and J.M. Marschall. 2013. Fire history in the Cherokee Nation of Oklahoma. Human Ecology 41: 749-758 https://doi.org/ 10.1007/s10745-013-9571-2

Stambaugh, M.C., R.P. Guyette, J.M. Marschall, and D.C. Dey. 2016. Scale dependence of oak woodland historical fire intervals: contrasting The Barrens of Tennessee and Cross Timbers of Oklahoma, USA. Fire Ecology 12 (2): 65-84 https://doi.org/10.4996/fireecology.1202065.

Stambaugh, M.C., K. Harper, J.M. Marschall, and R.P. Guyette. 2008. Tree ring data, post oak. French Lake, Wichita Mountains, OK (OK032). International tree-ring data bank. http://www.ncdc.noaa.gov/paleo/treering.html. Accessed 28 May 2017.

Stambaugh, M.C., J.M. Marschall, E.R. Abadir, B.C. Jones, P.H. Brose, D.C. Dey, and R.P. Guyette. 2018. Wave of fire: an anthropogenic signal in historical fire regimes across central Pennsylvania, USA. Ecosphere 9 (5): e02222 https://doi. org/10.1002/ecs2.2222.

Stambaugh, M.C., J.M. Marschall, and R.P. Guyette. 2014. Linking fire history to successional changes of xeric oak woodlands. Forest Ecology and Management 320: 83-95 https://doi.org/10.1016/j.foreco.2014.02.022.

Stambaugh, M.C., K.T. Smith, and D.C. Dey. 2017a. Fire scar growth and closure rates in white oak (Quercus alba) and the implications for prescribed burning. Forest Ecology and Management 391: 396-403 https://doi.org/10.1016/j.foreco.2017.02.005.

Stambaugh, M.C., J. Sparks, R.P. Guyette, and G. Willson. 2011. Fire history of a relict oak woodland in northeast Texas. Rangeland Ecology and Management 64: 419-423 https://doi.org/10.2111/REM-D-10-00128.1.

Stewart, O.C. 2002. Forgotten fires: Native Americans and the transient wilderness. Norman: University of Oklahoma Press.

Stokes, M.A., and T.L. Smiley. 1968. Introduction to tree-ring dating. Chicago: University of Chicago Press.

Swetnam, T.W., C.D. Allen, and J.L. Betancourt. 1999. Applied historical ecology: using the past to manage for the future. Ecological Applications 9: 1189-1206 https://doi.org/10.1890/1051-0761(1999)009[1189:AHEUTP]2.0.CO;2.

Swetnam, T.W., and C.H. Baisan. 1996. Historical fire regime patterns in the southwestern United States since A.D. 1700. In Fire effects in Southwestern forests: proceedings of the second La Mesa fire symposium. USDA Forest Service General Technical Report RM-GTR-286, ed. C.D. Allen, 11-32. Fort Collins: USDA Forest Service, Rocky Mountain Forest and Range Experiment Station https:// doi.org/10.2737/RM-GTR-286.

Taylor, A.H., V. Trouet, C.N. Skinner, and S. Stephens. 2016. Socioecological transitions trigger fire regime shifts and modulate fire-climate interactions in the Sierra Nevada, USA, 1600-2015 CE. Proceedings of the National Academy of Sciences 113: 13684-13689 https://doi.org/10.1073/ pnas.1609775113.

Therrell, M.D., and D.W. Stahle. 1998. A predictive model to locate ancient forests in the Cross Timbers of Osage County, Oklahoma. Journal of Biogeography 25 (5): 847-854 https://doi.org/10.1046/j.1365-2699.1998.00224.x.

Touchan, R., T.W. Swetnam, and H.D. Grissino-Mayer. 1995. Effects of livestock grazing on pre-settlement fire regimes in New Mexico. In Proceedings-symposium on fire in wilderness and park management. USDA Forest Service GTR-INT-320, ed. J.K. Brown, R.W. Mutch, C.W. Spoon, and R.H. Wakimoto, 268-272. Ogden: USDA Forest Service, Intermountain Research Station.

US Fish and Wildlife Service. 2006. Hagerman National Wildlife Refuge Comprehensive Conservation Plan. Albuquerque: US Fish and Wildlife Service https://www.fws.gov/uploadedFiles/Hagerman\%20CCP.pdf. Accessed 21 May 2019.

Waldman, C. 1985. Atlas of the North American Indian. New York: Facts on File, Inc.

Wildland Fire Leadership Council. 2014. The National Strategy: the final phase in the development of the National Cohesive Wildland Fire Management 
Strategy. p. 93. https://www.forestsandrangelands.gov/documents/strategy/ strategy/CSPhaselllNationalStrategyApr2014.pdf.

Williams, M. 1989. Americans and their forests: a historical geography. Cambridge: Cambridge University Press.

Wittry, W.L. 1961. Review: an archeological survey of the Ft. Sill military reservation, Oklahoma. OASP Paper No. 18. American Antiquity 27: 254-255.

Yocum Kent, L.L., P.Z. Fulé, P.M. Brown, J. Cerano-Paredes, E. Cornejo-Oviedo, C. Coretes Montaño, S.A. Drury, D.A. Falk, J. Meunier, H.M. Poulos, C.N. Skinner, S.L. Stephens, and J. Villanueva-Diaz. 2017. Climate drives fire synchrony but local factors control fire regime change in northern Mexico. Ecosphere 8 (3): e017 https://doi.org/10.1002/ecs2.1709.

\section{Publisher's Note}

Springer Nature remains neutral with regard to jurisdictional claims in published maps and institutional affiliations.

\section{Submit your manuscript to a SpringerOpen ${ }^{\circ}$ journal and benefit from:}

- Convenient online submission

- Rigorous peer review

- Open access: articles freely available online

- High visibility within the field

- Retaining the copyright to your article

Submit your next manuscript at $\boldsymbol{\nabla}$ springeropen.com 